\title{
Review Article \\ Eyewitness Science and the Call for Double-Blind Lineup Administration
}

\author{
Dario N. Rodriguez and Melissa A. Berry \\ Department of Psychology, University of Dayton, 300 College Park, Dayton, OH 45469-1430, USA \\ Correspondence should be addressed to Dario N. Rodriguez; drodriguez1@udayton.edu
}

Received 26 June 2012; Revised 12 August 2012; Accepted 27 August 2012

Academic Editor: Pär Anders Granhag

Copyright (c) 2013 D. N. Rodriguez and M. A. Berry. This is an open access article distributed under the Creative Commons Attribution License, which permits unrestricted use, distribution, and reproduction in any medium, provided the original work is properly cited.

\begin{abstract}
For several decades, social scientists have investigated variables that can influence the accuracy of eyewitnesses' identifications. This research has been fruitful and led to many recommendations to improve lineup procedures. Arguably, the most crucial reform social scientists advocate is double-blind lineup administration: lineups should be administered by a person who does not know the identity of the suspect. In this paper, we briefly review the classic research on expectancy effects that underlies this procedural recommendation. Then, we discuss the eyewitness research, illustrating three routes by which lineup administrators' expectations can bias eyewitness identification evidence: effects on eyewitnesses' identification decisions, effects on eyewitnesses' identification confidence, and effects on administrator records of the lineup procedure. Finally, we discuss the extent to which double-blind lineup administration has been adopted among police jurisdictions in the United States and address common concerns about implementing a double-blind standard.
\end{abstract}

\section{Introduction}

In April of 1980, 16-year-old Mario Hamilton was shot in the neck and killed in Brooklyn, New York. Thomas Charlemagne, 14, witnessed the shooting and ran to tell Mario's 15-year-old brother, Martell. The two boys went to the police station where they were questioned separately for over six hours. Charlemagne told the police he had seen a young man named Colin Warner, 18, shooting Mario and then flees the scene in a car driven by a 15-year-old boy named Norman Simmonds. Police showed a photo lineup that contained Warner to Martell. When he did not make an identification, officers presented Warner's photo alone and pressured Martell to identify him. Although Martell did not see the shooting first-hand, he eventually ceded to police suggestion and stated that he may have seen Warner near the scene of the crime, an identification that was used to secure Warner's indictment and conviction in May of 1982. Warner maintained his innocence, and in 1991, Simmonds signed an affidavit indicating that he alone was responsible for the murder of Mario Hamilton. Colin Warner was eventually exonerated in 2001 after spending almost 20 years in prison for a crime he did not commit $[1,2]$.

Unfortunately, cases like that of Colin Warner are not uncommon. The advent of DNA testing has shed some light on the frequency with which mistaken eyewitness identifications and wrongful convictions can occur. Recent analyses indicate that mistaken eyewitness identifications are a primary cause of wrongful conviction, associated with $43 \%$ of the nearly 900 documented wrongful convictions in the National Registry of Exonerations [1], and over 75\% of the nearly 300 DNA exonerations by the Innocence Project [3]. These figures, however, likely represent only the tip of the iceberg of the overall problem of wrongful convictions [4]. Sensational media coverage of wrongful conviction cases (e.g., the recent postexecution exoneration of Carlos DeLuna in Texas) as well as the popularity of television crime dramas like Law and Order and CSI have brought these issues into the public interest, and many in the criminal justice system have turned to social science research regarding the reliability of eyewitness identification evidence to further understand the causes and potential remedies of mistaken identifications. 
Eyewitness lineups are a common investigative tool used to ascertain if a suspect is guilty of a given crime. Witnesses to a crime are presented with an array of faces (either using photos or in person) and asked whether they recognize the perpetrator from among the presented faces. Witnesses' identifications of suspects from lineups are very influential. They are usually interpreted as evidence of the suspect's guilt and often result in indictment and conviction of the identified suspect [4]. However, social scientists have been questioning the reliability of eyewitness identifications and reports since as far back as the turn of the 20th century (e.g., [5-13]). Research on eyewitness identifications and testimony has developed quickly over the last several decades. By manipulating variables in the context of eyewitness experiments (see [14]), social scientists have identified numerous aspects of lineup procedures that can unduly influence witness identification behavior, as well as procedural reforms that can yield more diagnostic identifications (e.g., unbiased lineup instructions, sequential photo presentation [15-17]). Although some of these reforms have garnered some controversy (e.g., [18-20]), social scientists have been virtually unanimous regarding their recommendation of one procedural reform that virtually eliminates the potential for the administrator suggestiveness that appears to have played a large role in obtaining the lineup identification of Colin Warner and his subsequent wrongful conviction: doubleblind lineup administration $[15,21]$.

\section{Applying Social Science Research to Eyewitness Lineups}

Typically, a person who knows the identity of a suspect (e.g., investigating detective) administers a lineup to an eyewitness (i.e., single-blind administration [17]). Originally proposed over twenty years ago [22], the double-blind lineup recommendation is simple: the person who administers a lineup to a witness should not know the identity of the suspect. Although empirical research directly examining administrator blindness would not begin to develop until several years later, the recommendation was based on decades of social psychological research regarding experimenter expectancy effects.

\section{Social Psychological Research on Expectancy Effects}

Expectancy effects refer to the phenomenon whereby one's beliefs or expectations about another person elicit behavioral confirmation of those initial beliefs (self-fulfilling prophecy $[23,24])$. That is, one may unintentionally behave in such a way that causes another person to behave in accordance with one's expectations, often resulting in a strengthening of one's initial beliefs (irrespective of their objective veracity). Such an effect in the context of empirical research could be disastrous, leading to the unwitting contamination of data and perpetuation of false conclusions. The first evidence for expectancy effects in the context of a laboratory experiment was discovered accidentally. While collecting data for his dissertation, Robert Rosenthal realized he may have unintentionally influenced his participants to behave in accordance with his research hypothesis [25]. To examine this possibility, he then conducted a series of experiments examining if and how an experimenter's expectations can influence the outcome of a study. In the first experimental examination of experimenter expectancy effects, Rosenthal and Fode [26] asked student experimenters to conduct an experiment on social judgments of facial appearance and try to replicate a "well-established" finding. All experimenters were given strict instructions on how to conduct the study. However, half of the experimenters were led to believe that their participants would view the presented faces as "successful," whereas the other half were led to believe that their participants would view the presented faces as "unsuccessful." Student experimenters then collected data from independent groups of research participants. The results showed that experimenters expecting to receive higher ratings of "success" obtained significantly higher success ratings than those experimenters expecting to receive lower ratings. Experimenters' expectations influenced the data they obtained from their studies. Follow-up studies of experimenter expectancy effects yielded similar findings $[27,28]$.

Hundreds of experiments have since demonstrated that experimenters' expectations regarding the outcome of their study can influence the data they obtain $[24,25]$. The effects even generalize to research conducted with nonhuman participants (e.g., rats [29, 30]). Experimenter expectancy effects are not confined to the laboratory. Rather, expectations influence behavior and data in a wide variety of contexts. For example, expectancy effects were found to influence children's academic development in what is now widely known as the Pygmalion Experiment $[31,32]$. Children at an elementary school completed an intelligence test that was disguised as a test predicting intellectual "blooming." Students in each classroom were then randomly selected to form the experimental condition. Teachers were given the names of these students and were told that their test scores indicated that they would show surprising intellectual gains over the school year. In reality, the only difference between the two groups was the teachers' expectations for their performance. At the end of the school year, all children were retested. Children in the experimental group showed significantly greater intellectual gains than children in the control group. This experiment was the first to show that expectancy effects can influence others' behavior in real-world situations. Other experiments have demonstrated the contaminating effects of expectations in such disparate contexts as medical research $[33,34]$, the financial sector [35], and even juror decisionmaking $[36,37]$.

Researchers can influence participants' behaviors in many ways (e.g., paralinguistic cues, body language, and verbal reinforcement of desired responses [29]), and social scientists have developed a number of options for limiting the influence of researcher expectations via these routes (e.g., standardization of research procedure via scripts or computerization). One strategy that effectively eliminates the influence of expectations is the use of double-blind experimentation. In double-blind research, the researcher 
does not know the expected results of the study or does not know which condition of an experiment is being tested at a given time. As a result, he or she cannot engage in behaviors that differentially contaminate data or influence participants' behaviors in accordance with the research hypotheses. This technique has become standard procedure in much social science and medical research.

\section{Eyewitness Lineups as Social Psychology Experiments}

Supporting Wells's [22] recommendation, Wells and Luus [38] illustrated how this crucial double-blind procedure applies to eyewitness lineups by comparing a lineup task to a social psychology experiment. Just as a researcher forms a hypothesis and designs an experiment to test that hypothesis, a detective believes he or she knows the perpetrator of the given crime and asks an eyewitness to view a lineup to test that belief. Consequently, the same factors that introduce bias into social psychology experiments also introduce bias into lineup tasks. Single-blind administration is one such procedure that can bias lineup outcomes. Administrators who know the identity of the suspect in a lineup may inadvertently steer witnesses' decisions in accordance with their hypothesis (i.e., that the suspect is the perpetrator of a given crime). For example, if a witness is unable to choose between identifying the suspect or a filler (i.e., known innocent lineup member used to "fill out" a lineup), a single-blind administrator might ask about how the suspect's appearance matches the witness's memory, but not ask such questions regarding the filler's appearance, cueing to the witness which lineup member he or she should identify. Similarly, when considering a filler identification, a single-blind administrator may encourage witnesses to "take their time," effectively discouraging them from identifying the person they were considering. Singleblind administration also opens the door to subtle influences via the routes social scientists have identified (e.g., nonverbal behavior [29]); these systematic influences are not possible with double-blind administration. It is important to note that these influences are not necessarily intentional. Nonetheless, these processes are problematic, especially when an innocent suspect is in the lineup. An innocent suspect, who is the focus of a single-blind administrator's attention, is at higher risk for mistaken identification from single-blind rather than doubleblind lineups

[15].

\section{Lineup Administrator Blindness Effects in Eyewitness Research}

Although research on expectancy effects has provided strong support for the recommendation of double-blind administration for several decades, social scientists have only relatively recently begun investigating the influence of administrator blindness on lineup outcomes directly. This research has revealed three distinct routes by which lineup administrator blindness may influence eyewitness identification evidence.

\section{Blindness Affects Eyewitness's Identifications}

Just as experimenters can steer their participants to behave in accordance with their expectations [26], lineup administrators may inadvertently steer witnesses to identify the suspect in a lineup. In the first experimental investigation of these potential lineup administrator blindness effects, Phillips et al. [39] randomly assigned research participants to the roles of lineup administrator and eyewitness. Witnesses viewed a mock crime while administrators received training in lineup presentation. Afterward, administrators presented to witnesses two lineups that did not contain the perpetrators they had witnessed (i.e., target-absent lineups). For one lineup, administrators were informed of the (innocent) suspect's identity (i.e., single-blind administration), whereas for the other lineup, they were not (i.e., double-blind administration). Administrators presented lineup photos either sequentially or simultaneously (see [40]), with an experimenter observer either present or absent. A significant three-way interaction $\left(\eta^{2}=.09\right)$ on false identifications emerged. Single-blind administration (56\%) increased false identification rates of the innocent suspect (relative to doubleblind administration: $8 \%$ ) from sequential lineups when an observer was present. A similar investigation of administrator blindness using target-absent lineups presented either sequentially or simultaneously yielded differing results [41]: whereas false identification rates did not differ as a function of lineup type in double-blind conditions, witnesses in simultaneous $(76 \%)$ conditions were more sensitive to administrator steering toward the suspect (i.e., false identification) relative to those in sequential conditions $(44 \%, \phi=.16)$. Additionally, a conceptually related study was aimed at investigating administrator-witness contact (high versus low interaction) using sequential and simultaneous, target-present and targetabsent lineups [42]. In high-contact conditions, administrators sat very near to and in front of, or beside witnesses during the lineup task; in low-contact conditions, administrators sat further away and behind witnesses during the lineup task. The researchers found that witnesses' identifications conformed to administrators' expectations most frequently when a highcontact administrator administered a simultaneous lineup; significant effect sizes $(\phi)$ ranged from .15 to .18. Other studies, however, have yielded null or inconsistent effects of lineup administrator knowledge of eyewitness identification decisions (e.g., [43-47]).

Greathouse and Kovera [48] conducted an experiment in an attempt to make sense of the disparate administrator blindness effects. They argued that, whereas research on expectancy effects in other domains (e.g., education, animal behavior) involved shaping the behavior of targets who have the capacity to change their behaviors in expectancyconsistent ways, lineup tasks involve targets whose behavior (identification decision) may or may not be susceptible to influence. The witness's metacognitive assessments (e.g., certainty, memory strength) moderate administrator influence. For example, witnesses who are highly confident that the perpetrator of a crime is not in the lineup will not likely be influenced by a single-blind administrator's steering to identify the suspect because the suggestion is inconsistent 
with their memories. Likewise, witnesses who confidently identify fillers will not be influenced. However, some witnesses identify fillers (and suspects [49]) merely because they are guessing and they are not confident in the quality of their memory. These witnesses are likely to be the ones who are susceptible to administrator influence because they are more capable of changing their behavior in expectancy-consistent ways. As a result, Greathouse and Kovera hypothesized that administrator blindness effects may only be observable under conditions that promote eyewitness guessing (i.e., lower witnesses' response criterion: simultaneous lineups, biased instructions). Supporting their hypothesis, the results of their experiment showed that single-blind administration $(60 \%)$ increased suspect identifications relative to doubleblind administration (32\%) in both target-present and targetabsent arrays when the administrator used a simultaneous lineup and biased lineup instructions. As a result, the overall diagnosticity (Diagnosticity is a measure of the probability that a classification (suspect identification or lineup rejection) is accurate (see [50])) of eyewitnesses' lineup choices in single-blind conditions was only half of that obtained in double-blind conditions. More recent studies have revealed administrator blindness effects that are relatively consistent with these results (e.g., [51-53]), and a recent meta-analysis has confirmed that single-blind/high-contact administration yields higher rates of false identifications than doubleblind/low-contact administration [54].

It is conceivable that should police adopt the double-blind administration procedure, the same double-blind administrator might present a lineup to multiple eyewitnesses in the same case. Recent findings indicate that even doubleblind administrators may inadvertently use one eyewitnesses' decision to influence another's, despite possessing no knowledge of the suspect's identity. In one study, double-blind participant administrators presented a target-absent lineup to a confederate who made an identification with either high or low confidence [55]. Afterward, those administrators presented the same lineup to a participant witness. Witnesses were more likely to make the same identification decision as the confederate when she made an identification with low confidence (32\%) than when she made an identification with high confidence (16\%). These results were in the opposite direction from the research hypothesis; they indicate, however, that administrators used the first witness's decision to influence the identification of the second witness.

Research has yet to reveal any precise boundary conditions for observing administrator blindness effects on witnesses' identification decisions. Additionally, a recent analysis shows that double-blind administration is associated with a reduction in accurate identifications of suspects in addition to a reduction in false identifications (see $[54,56]$ ), causing some to reconsider the double-blind administration recommendation. It should be noted, however, that identification decisions in double-blind conditions represent witnesses' behaviors without any specific influence from a lineup administrator (e.g., a "baseline"). Thus, any significant deviation from these identification rates in singleblind conditions represents the influence of administrator bias [16]. Increased false identification rates suggest a clear drawback of single-blind administration. However, increased accurate identifications in single-blind conditions are also the product of administrator influence and do not constitute a benefit of the suggestive procedure. Suspect identifications made from single-blind lineups cannot be considered wholly independent of administrators' influence, and thus do not satisfy the intended function of eyewitness identification evidence (i.e., independent verification of a suspect's guilt). Although the use of double-blind administration does not eliminate all sources of lineup bias (e.g., instruction bias, filler quality), it does ensure that at least one source of bias has been eliminated from witnesses' decisions.

Overall, this body of research indicates that single-blind lineup administration can shift eyewitnesses' identification decisions toward the suspect (whether innocent or guilty), resulting in a decrease in decision diagnosticity. Doubleblind administration, however, does not shift witnesses' decisions and consistently yields higher diagnosticity. Additionally, results from the investigations of administrators who conduct multiple lineups suggest that the same doubleblind administrator should not be used for more than one lineup for a particular suspect [55]. However, there has been relatively little consistency in the conditions under which blindness effects have been obtained, and there were no published studies of administrator blindness effects using real lineup administrators (cf. [18]). Future research should be directed at pinpointing the boundary conditions of administrator blindness effects and establishing the external validity of laboratory results (see $[52,57]$ ).

\section{Blindness Affects Eyewitnesses' Identification Confidence}

Witnesses' testimony regarding their identifications is very powerful evidence at trial. Jurors tend to evaluate witnesses relatively favorably, overall, and tend to equate confidence with identification accuracy [58]. Indeed, current legal criteria encourage judges and jurors to consider confidence when evaluating eyewitness testimony (see [59]). In addition to influencing witnesses' identifications, a large body of research has shown that comments made by a single-blind administrator can have profound distorting effects on witness confidence.

In the first study of what is now known as the postidentification feedback effect, Wells and Bradfield [60] asked witnesses to view a crime video and then make an identification from a target-absent lineup. Following the identification, witnesses received confirming feedback ("Good, you identified the actual suspect"), disconfirming feedback ("Actually, the suspect is number __"), or no feedback. Feedback had dramatic effects on witnesses' retrospective reports of testimonyrelevant variables (e.g., confidence in their selections at the time of the identification; quality of their view of the perpetrator at the time of the crime), which were rated on $7 \mathrm{pt}$ scales. Witnesses who received confirming feedback reported inflated ratings on testimony-relevant variables relative to the no-feedback group (average $d=.78$ ), and those who received disconfirming feedback reported deflated ratings 
relative to the no-feedback group (average $d=-.29$ ). That is, confirming feedback made witnesses appear more confident and more credible (on prescribed criteria for evaluating eyewitness evidence [59]), despite they all making incorrect identifications. This effect is robust and has been replicated numerous times (e.g., [61-63]). A recent meta-analysis also indicates reliable, though smaller, effects of postidentification feedback on more "objective" retrospective measures, such as witnesses' reports of the length of time the perpetrator was in view and their distance from the perpetrator [64]. (It is worth noting, however, that in a recent examination of the locus of postidentification feedback effects, Douglass et al. [65] failed to find any significant effects of feedback on objective selfreport measures.), and this effect has been demonstrated with real-world eyewitnesses as well as laboratory participants [66].

Although the influence of feedback provided by a singleblind administrator is well documented, relatively little research has directly manipulated administrator expectations or blindness to examine their effects on postidentification feedback and confidence. However, some evidence does suggest that administrator expectations can influence witnesses' self-reported confidence. In one study, witnesses viewed a crime video and then made an identification from a targetabsent lineup administered by another participant [67]. Experimenters manipulated administrators' expectations by telling them that different lineup members were the suspect (i.e., some were told the suspect was number 5 in the lineup, whereas others were told the suspect was a different numbered photo, or were not told anything). Results showed that administrator expectations affected the confidence witnesses expressed in their identifications. Witnesses who selected a lineup member whom administrators believed to be a suspect expressed higher confidence on a 10 pt scale than those in the control group (i.e., double-blind administration: $d=$ 2.17) as well as those who selected a member who administrators believed to be a filler (average $d=1.80$ ), despite all identifications being factually incorrect. These results suggest that expectations regarding a suspect's identity can lead administrators to offer spontaneous feedback regarding witnesses' identification performance, which in turn affects witnesses' reports of identification confidence.

Researchers have recently examined the ability of doubleblind lineup administration to eliminate the postidentification feedback effect [68]. In this study, witnesses viewed a crime video and then made an identification from either a target-preset or target-absent lineup, which was presented by a presumed single-blind or a presumed double-blind lineup administrator. The experimenters manipulated whether the witnesses believed the administrator knew the identity of the perpetrator with an instruction and by altering whether the administrator was present when the witness viewed the crime video. Afterward, half of the administrators (both singleand double-blind) offered a form of postidentification feedback that is reassuring, but not identification-specific and, arguably, more closely approximates what real lineup administrators are likely to say to witnesses (i.e., "Thank you. You have been a really great witness."). Results showed that, for witnesses who made incorrect decisions, postidentification feedback inflated retrospective reports (e.g., identification confidence (see [60])) in presumed single-blind conditions (multivariate $\eta_{p}^{2}=.13$ ), but not in presumed double-blind conditions (multivariate $\eta_{p}^{2}=.05$ ). This interaction did not emerge for witnesses who made correct decisions, indicating that inaccurate witnesses may actually appear more credible as a function of suggestive feedback than accurate witnesses (see [21]). Overall, these results provide initial support for the assertion that double-blind administration can eliminate the postidentification feedback effect, if witnesses are indeed aware that the administrator does not know the identity of the suspect in the lineup.

It is clear from this body of research that comments made by a single-blind administrator can radically distort witnesses' reports on testimony-relevant variables. Although it is impossible to prevent witnesses from receiving any and all feedback on their decision (e.g., an indictment is a form of implicit confirming feedback), double-blind lineup administrators can record purer measures of confidence because they are unable to provide any verbal or nonverbal (dis)confirmation that might influence witnesses' reports [67]. Additionally, any form of feedback, even feedback that is not identification-specific, can be damaging if the doubleblind technique is not employed and if witnesses are unaware that the administrator does not know the suspect's identity in the lineup [68].

The distorting effects of single-blind administrators' comments have been firmly established. This area of inquiry might benefit most from investigations into two aspects of the postidentification feedback effect. First, researchers should devote more attention to understanding the mechanism that underlies the effect. One critical test of competing mechanisms suggests that a cues-based conceptualization may best account for the effect (see [69]); that is, witnesses who lack strong internal cues to identification accuracy (i.e., they have weak memories) may infer their identification confidence based on cues from a lineup administrator's comments. Findings from such theoretically driven investigations may have implications for many areas of the eyewitness literature beyond merely the effects on witnesses' retrospective reports (e.g., postevent suggestion and interviewing). Secondly, social scientists should investigate the locus of the postidentification feedback effect in an effort to more fully understand the range of variables on which witnesses' reports may be distorted by explicit or implicit feedback [65].

\section{Blindness Affects Administrators' Records of the Lineup Task}

Three police jurisdictions in Illinois participated in a field study on the effectiveness of sequential double-blind lineups, conducted under the direction of general counsel for the Chicago Police [18]. The results appeared to contradict those of laboratory research regarding the superiority of the sequential lineup (relative to the simultaneous lineup (see [70])). A closer inspection of the research design used in the field study reveals that the two variables of interest, 
lineup presentation (i.e., sequential or simultaneous) and administrator blindness (i.e., single- or double-blind), were confounded: sequential lineups were always administered by a double-blind administrator, whereas simultaneous lineups were always administered by a single-blind administrator. The scientific community has virtually unanimously agreed that this confound is a fatal flaw, preventing us from attributing the differences in eyewitnesses' selections between the two conditions to either lineup format or administrator blindness (see $[19,20]$ ).

The Illinois study did, however, yield some interesting results. In a reanalysis of a subset of the data, Steblay [71] found that the records of the lineup task differed between the two conditions. Single-blind administrators were more likely to record vague, third person accounts of witnesses' decisions, which obscure valuable information about certainty (e.g., "the victim made a positive ID," p. 6), whereas double-blind administrators were more likely to record verbatim responses, which did not obscure this information (e.g., "that's her, she's got gold teeth", p. 6). Although these differences may be attributable to differences in protocol between the two conditions, they elucidate the possibility that blindness can influence administrator records of lineup outcomes. Social scientists have also speculated that administrators' knowledge of suspects' identities may have influenced administrators' likelihood of distinguishing filler identifications (known errors) from nonidentifications [57, 71]. Specifically, single-blind administrators may have been less likely than double-blind administrators to record filler identifications as positive identifications (which would discredit a witness from future use), opting instead to mark their decisions as no-choice responses (preserving the witness for future use). Indeed, social science research regarding confirmation bias shows that this is possible: expectations influence the way that people interpret and weight expectancy-relevant information (for a review, see [72]). Specifically, people have a tendency to seek out and emphasize expectancy-consistent information (i.e., suspect identification) and overlook or ignore expectancy-inconsistent information (i.e., filler identification).

Some evidence of this possibility in the eyewitness realm was obtained in two archival analyses of real eyewitnesses in California and Canada (see [73] and [74], resp.). When analyzing the data, researchers had difficulty computing filler identification rates because single-blind administrators frequently recorded filler identifications as nonidentifications. The lack of experimental manipulation of administrator blindness in these studies, however, prohibited inferring a causal relationship between expectations and recording decisions. Recent research attention has been directed at addressing this shortcoming. In the first experimental test of this relationship, single- and double-blind participants administered a lineup to a confederate, who identified either the suspect or a filler [75]. The results showed that singleblind administrators were more likely to record suspect selections (82\%) and less likely to record filler selections (56.5\%) as positive identifications compared to doubleblind administrators, who were not influenced by the witness's selection (suspect: 69.8\%; filler: $76.2 \%$ ). These findings provided empirical support for speculation regarding singleblind administration suppressing filler identifications [57, 71]. Also, these results may actually underestimate the size of blindness effects on lineup records in the field. Administrators were not given additional motivation to obtain suspect identifications (e.g., monetary incentive [48]), and unlike actual lineup administrators, they had no prior experience with, or vested interest in the case. The motivational factors present in real-world lineup situations may exaggerate the differences obtained in this study. Although more research is needed to establish the locus of this blindness effect (e.g., effects on completeness of lineup records) and its generality (e.g., studies using actual lineup administrators), these findings suggest that administrator blindness can influence the record of lineup outcomes that is entered into evidence.

\section{Adopting Double-Blind Lineup Administration}

Numerous jurisdictions in the United States and Europe have begun to recognize the usefulness of double-blind administration [16]. The Technical Working Group for Eyewitness Evidence [76], an interdisciplinary committee convened by former attorney general Janet Reno that included social scientists, attorneys, and police officers, identified double-blind lineup administration as a procedure worth considering, but fell short of including it among its formal recommendations. Soon after, New Jersey was among the first to adopt an entire package of lineup reforms, including double-blind administration [77]; other United States jurisdictions, including the states of Wisconsin, Ohio, North Carolina, Texas, and Connecticut, as well as the cities of Boston, Dallas, and Denver, among others, have also made double-blind lineup administration standard procedure. Double-blind administration has also become a staple reform advocated by legal organizations, such as the Innocence Project [78], the American Bar Association [79], and the International Association of Chiefs of Police [80], as well as research societies (e.g., American Psychology-Law Society [17]).

Despite this progress, however, many law enforcement offices are resistant to adopting the double-blind procedure, and single-blind lineup administration remains standard procedure in much of the United States. One of the more widely cited reports reflecting this sentiment is that of the Illinois field study on sequential, double-blind lineups, which contains a number of concerns regarding the adoption of a double-blind lineup administration standard [18]. First, it is stated that double-blind lineup administration would not solve the issue of postidentification feedback: a witness may still receive feedback from an investigating detective when he or she learns of the lineup outcome, and the progression of a case through to prosecution suggests that the witness identified the suspect. Indeed, double-blind administration cannot eliminate all sources of feedback. However, a doubleblind administrator can collect a confidence statement from witnesses before any sources of feedback distort their retrospective reports (e.g., administrator verbal or nonverbal cues [67]). Any subsequent expressions of confidence, which 
may be distorted by feedback, can then be compared to this initial, relatively unbiased confidence record. Data suggest that, under some circumstances, triers of fact can adjust their legal judgments when presented with disparities between witnesses' initial and in-court expressions of confidence (see $[81,82])$. Thus, though it does not eliminate all feedback effects, double-blind administration can provide information to help counteract feedback effects in court above and beyond information gathered from single-blind lineups.

A second concern is that double-blind administration may result in a loss of evidence. Because they have not established rapport with witnesses, double-blind administrators may not recognize a witness's discomfort or fear and may not be able to "allay the witness's fear or reluctance to make an identification" [18, p. 57]. It should be noted, however, that it is precisely that these types of ambiguous situations in which expectancy effects are most powerful (see, e.g., $[72,83])$. Single-blind administrators may be more likely to interpret ambiguous behaviors as evidence of trepidation and unintentionally cue witnesses to make identifications; a double-blind administrator can offer comfort if such emotions are perceived, but is unable to cue the witness to identify a particular lineup member, preserving the independence of the witnesses' identification from the administrators' expectations. A related concern is that double-blind administrators' lack of familiarity with case details may lead them to miss witnesses' utterances that could contain exculpatory information (which should be disclosed to the defense). It is unclear what types of exculpatory statements would be undetectable by double-blind administrators. Nonetheless, this concern can be addressed by instructing double-blind administrators to record all statements a witness makes during a lineup task. Indeed, double-blind administrators are frequently directed to record all aspects of the identification procedure [71].

One major concern often expressed is that doubleblind lineup administration would place too much strain on police department resources [18]. For example, double-blind administration may require that more officers be present in the station instead of in the field and may entail a longer delay before conducting a lineup task. Similarly, doubleblind administration may not always be feasible for police jurisdictions with a small number of employed officers, for big cases with multiple witnesses, or for cases involving chronic offenders who are repeatedly placed in lineups. These types of situations may in fact make double-blind administration infeasible. Although the data on this issue are limited, it appears that these types of problems would only influence a minority of cases and officers would be able to follow a double-blind administration standard most of the time. Data from the New Jersey Attorney General survey on eyewitness identification practices (see Tables 1.1, 1.2, and 1.3 in [18]) indicate that $77 \%$ of police departments (ranging from 2 to 2000 employees) report using double-blind administration "in every case" or "in almost every case." The data do not directly speak to the reasons for noncompliance with the double-blind standard, but they indicate that, overall, the standard has been adopted in the vast majority of cases. Additionally, it appears reasonable to construct lineup standards in accordance with empirically supported "best practices," rather than based on special situations that may preclude them.

An interesting concern voiced in the report resulting from the Illinois field study is that not all lineups take place in the police station, and that this trend will likely escalate as technological advances allow officers to conduct lineups electronically on portable devices [18]. Technological advancements in the creation and conduct of lineups, however, do not necessarily eliminate the possibility of doubleblind lineup administration. Indeed, computerization of lineups is a tool that social scientists frequently use to ensure double-blind lineup administration in their experiments. Additionally, in a recent American Judicature Society field study on double-blind sequential and simultaneous lineups [57], four participating police jurisdictions in four different states administered double-blind lineups using laptop computers and a streamlined software program that recorded pertinent case facts, witnesses' identification decisions, and an audio file containing the entire interaction between the witness and administrator. It appears that such advancements would actually enable double-blind administration rather than prohibiting it. Moreover, the adoption of such programs that can record audio of a lineup task would further address previous concerns regarding evidence potentially "lost" from double-blind administration by providing greater information regarding the witnesses' memories (see [84]).

Finally, one obstacle to the adoption of double-blind administration is that, often, police officers do not understand the benefits of the reform. Indeed, research frequently shows that people are not sensitive to the influence of administrator blindness on eyewitness identification decisions (e.g., $[85,86])$. People generally tend to trust eyewitnesses and fail to adjust their evaluations downward when presented with information that should reduce witness credibility (e.g., [87]). This, however, does not appear to be sufficient reason for policy makers to resist the double-blind procedure. Additionally, though some police may not fully appreciate the benefits of the reform with respect to the reliability of eyewitness evidence, many have acknowledged that adopting double-blind administration would likely "reduce claims of officer misconduct" [18, p. 57]. Rather than try to teach legal actors to adjust their witness evaluations to account for poor procedures after they have happened, social scientists and policy makers should work toward elevating the reliability of eyewitness evidence to meet their expectations by instating procedures that prevent errors and bias. Doubleblind administration is one procedure that, combined with other advocated reforms (e.g., unbiased instructions), helps to eliminate such bias.

Though additional research is necessary to fully explore the intricacies of administrator blindness effects, overall, it appears that the potential drawbacks to the adoption of double-blind administration would be far outweighed by its benefits and law enforcement jurisdictions should seek to incorporate double-blind administration among its standard lineup procedures. An absolute mandate that all lineups and photoarrays are conducted by a double-blind administrator does not seem to be appropriate as, certainly, situations 
may arise in which double-blind administration is not feasible. Instead, interested policy makers can look toward standards implemented by New Jersey [76] and Wisconsin [88], which explicitly state that double-blind administration is the preferred procedure, but recognize that it may not always be a viable option: officers are instructed to administer double-blind lineups whenever possible. Such policies begin the process of instituting new standards and hold officers accountable for deviating from best practices, while allowing for the possibility of special circumstances that prevent their use. Alternatively, jurisdictions could designate lineup administrators within each department (see, e.g., Dallas). Such a program would ensure that dedicated administrators are always available and remain double-blind. Although instituting double-blind administration procedures would require law enforcement offices to train their lineup administrators, numerous jurisdictions in the United States and Europe have shown that it is possible (often within a relatively short window: 180 days in New Jersey) and have been pleased with the results.

\section{Conclusion}

Taken together, social science research clearly demonstrates that lineup administrators' expectations unduly influence eyewitness evidence via three routes: single-blind administration can (1) steer witnesses' decisions toward suspect identifications, (2) distort eyewitnesses' retrospective reports on testimony-relevant variables (such as identification confidence), and (3) alter the records of lineup outcomes. In light of the criteria by which legal actors are encouraged to evaluate eyewitness evidence (e.g., retrospective confidence [59]), single-blind administration can potentially increase the risk for mistaken identification and wrongful conviction [21]. Double-blind lineup administration, a relatively easy reform to implement, helps to guard against these risks by ensuring that administrator expectations do not taint eyewitness evidence. It is important that social scientists continue to advocate that double-blind administration becomes standard lineup procedure. Although this critical procedure cannot wholly eliminate mistaken eyewitness identifications, it can form the basis of other procedural reforms and help eliminate miscarriages of justice that result from expectancy effects, such as in the case of Colin Warner.

\section{Acknowledgments}

Portions of this paper were presented at the Ohio Attorney General "Evaluating Witnesses and their Testimony" Continuing Legal Education Seminars in Reynoldsburg, Ohio, in June, 2012.

\section{References}

[1] S. R. Gross and M. Shaffer, "Exonerations in the United States, 1989-2012: A report by the National Registry of Exonerations," 2012, http://www.law.umich.edu/special/exoneration/ Documents/exonerations_us_1989_2012_full_report.pdf.
[2] National Registry of Exonerations, "Exoneration case detail: Colin Warner," 2012, http://www.law.umich.edu/special/exoneration/Pages/casedetail.aspx? caseid=3718.

[3] Innocence Project, 2012, http://www.innocenceproject.org/.

[4] G. L. Wells, A. Memon, and S. D. Penrod, "Eyewitness evidence: improving its probative value," Psychological Science in the Public Interest, vol. 7, no. 2, pp. 45-75, 2006.

[5] G. F. Arnold, Psychology Applied to Legal Evidence and Other Constructions of Law, Thacker, Spink \& Co, Calcutta, India, 1906.

[6] A. Binet, On Suggestibility, Schleicher, Paris, France, 1900.

[7] C. Lombroso, L'Uomo Delinquente, Hoepli, Milan, Italy, 1876.

[8] H. Münsterberg, On the Witness Stand, Doubleday, New York, NY, USA, 1908.

[9] L. W. Stern, "The statement as a mental achievement and product of interrogation," Beiträge zur Psychologie der Assuage, vol. 3, pp. 269-415, 1904.

[10] G. M. Whipple, "The obtaining of information: psychology of observation and report," Psychological Bulletin, vol. 15, no. 7, pp. 217-248, 1918.

[11] G. M. Whipple, "Recent literature on the psychology of testimony," Psychological Bulletin, vol. 7, no. 11, pp. 365-368, 1910.

[12] G. M. Whipple, “The psychology of testimony," Psychological Bulletin, vol. 8, no. 9, pp. 307-309, 1911.

[13] G. M. Whipple, "Psychology of testimony and report," Psychological Bulletin, vol. 9, no. 7, pp. 264-269, 1912.

[14] G. L. Wells and S. D. Penrod, "Eyewitness identification research: strengths and weaknesses of alternative methods," in Research Methods in Forensic Psychology, B. Rosenfeld and S. D. Penrod, Eds., pp. 237-256, John Wiley and Sons, Hoboken, NJ, USA, 2011.

[15] G. L. Wells, "Eyewitness identification: systemic reforms," Wisconsin Law Review, vol. 2006, no. 2, pp. 615-643, 2006.

[16] G. L. Wells, N. K. Steblay, and J. E. Dysart, "Eyewitness identification reforms: are suggestiveness-induced hits and guesses true hits?" Perspectives on Psychological Science, vol. 7, pp. 264-271, 2012.

[17] G. L. Wells, M. Small, S. Penrod, R. S. Malpass, S. M. Fulero, and C. A. E. Brimacombe, "Eyewitness identification procedures: recommendations for lineups and photospreads," Law and Human Behavior, vol. 22, no. 6, pp. 603-647, 1998.

[18] S. H. Mecklenburg, Report to the Legislature of the State of Illinois: The Illinois Pilot Program on Sequential Double-Blind Identification Procedures, Illinois State Police, Springfield, Ill, USA, 2006.

[19] D. L. Schacter, R. Dawes, L. L. Jacoby et al., "Policy forum: studying eyewitness investigations in the field," Law and Human Behavior, vol. 32, no. 1, pp. 3-5, 2008.

[20] G. L. Wells, "Field experiments on eyewitness identification: towards a better understanding of pitfalls and prospects," Law and Human Behavior, vol. 32, no. 1, pp. 6-10, 2008.

[21] G. L. Wells and D. S. Quinlivan, "Suggestive eyewitness identification procedures and the supreme court's reliability test in light of eyewitness science: 30 years later," Law and Human Behavior, vol. 33, no. 1, pp. 1-24, 2009.

[22] G. L. Wells, Eyewitness Identification: A System Handbook, Carswell Legal Publications, Toronto, Ontario, Canada, 1988.

[23] R. Rosenthal, "Interpersonal expectancy effects: a 30-year perspective," Current Directions in Psychological Science, vol. 3, pp. 176-179, 1994. 
[24] R. Rosenthal, "Covert communication in classrooms, clinics, courtrooms, and cubicles," The American Psychologist, vol. 57, no. 11, pp. 839-849, 2002.

[25] R. Rosenthal, "From unconscious experimenter bias to teacher expectancy effects," in Teacher Expectancies, J. G. Dusek, V. C. Hall, and W. J. Meyer, Eds., pp. 37-65, Erlbaum, Hillsdale, NJ, USA, 1985.

[26] R. Rosenthal and K. L. Fode, "Three experiments in experimenter bias," Psychological Reports, vol. 12, pp. 491-511, 1963.

[27] R. Rosenthal, "Interpersonal expectations," in Artifact in Behavioral Research, R. Rosenthal and R. L. Rosnow, Eds., pp. 181-277, Academic Press, New York, NY, USA, 1969.

[28] R. Rosenthal and D. B. Rubin, "Interpersonal expectancy effects: the first 345 studies," Behavioral and Brain Sciences, vol. 1, no. 3, pp. 377-415, 1978.

[29] R. Rosenthal and K. L. Fode, "The effect of experimenter bias on the performance of the albino rat," Behavioral Science, vol. 8, pp. 183-189, 1963.

[30] R. Rosenthal and R. Lawson, "A longitudinal study of the effects of experimenter bias on the operant learning of laboratory rats," Journal of Psychiatric Research, vol. 2, no. 2, pp. 61-72, 1964.

[31] R. Rosenthal and L. Jacobson, "Teachers' expectancies: determinants of pupils' IQ gains," Psychological Reports, vol. 19, no. 1, pp. 115-118, 1966.

[32] R. Rosenthal and L. Jacobson, Pygmalion in the Classroom: Teacher Expectations and Pupils' Intellectual Development, Holt, Rinehart, \& Winston, New York, NY, USA, 1968.

[33] N. Ambady, D. LaPlante, T. Nguyen, N. Chaumeton, W. Levinson, and R. Rosenthal, "Surgeons' tone of voice: a clue to malpractice history," Surgery, vol. 132, no. 1, pp. 5-9, 2002.

[34] L. A. Learman, J. Avorn, D. E. Everitt, and R. Rosenthal, "Pygmalion in the nursing home: the effects of caregiver expectations on patient outcomes," Journal of the American Geriatrics Society, vol. 38, no. 7, pp. 797-803, 1990.

[35] T. Kida, "The impact of hypothesis-testing strategies on auditors' use of judgment data," Journal of Accounting Research, vol. 22, pp. 332-340, 1984.

[36] P. D. Blanck, R. Rosenthal, A. J. Hart, and F. Bernieri, "The measure of the judge: an empirically-based framework for exploring trial judges' behavior," Iowa Law Review, vol. 75, pp. 653-684, 1990

[37] A. M. Halverson, A. J. Hart, M. Hallahan, and R. Rosenthal, "Reducing the biasing effects of judges' nonverbal behavior with simplified jury instruction," Journal of Applied Psychology, vol. 82, no. 4, pp. 590-598, 1997.

[38] G. L. Wells and E. Luus, "Police lineups as experiments: social methodology as a framework for properly conducted lineups," Personality and Social Psychology Bulletin, vol. 16, pp. 106-117, 1990.

[39] M. R. Phillips, B. D. McAuliff, M. B. Kovera, and B. L. Cutler, "Double-blind photoarray administration as a safeguard against investigator bias," Journal of Applied Psychology, vol. 84, no. 6, pp. 940-951, 1999.

[40] R. C. L. Lindsay and G. L. Wells, "Improving eyewitness identifications from lineups. Simultaneous versus sequential lineup presentation," Journal of Applied Psychology, vol. 70, no. 3, pp. 556-564, 1985.

[41] A. H. Perlini and A. D. Silvaggio, "Eyewitness misidentification: single versus double-blind comparison of photospread administration," Psychological Reports, vol. 100, no. 1, pp. 247-256, 2007.
[42] R. M. Haw and R. P. Fisher, "Effects of administrator-witness contact on eyewitness identification accuracy," Journal of Applied Psychology, vol. 89, no. 6, pp. 1106-1112, 2004.

[43] J. L. Beaudry, Video-recorded lineup procedures and detecting identification accuracy [Doctoral dissertation], Queens University, Ontario, Canada, 2008.

[44] J. E. Dysart and L. Fugal, "Improving the sequential lineup? The effects of double blind testing and the envelope technique on post-identification feedback," in Proceedings of the American Psychology Law Society Annual Meeting, St. Petersburg, Fla, USA, March 2006.

[45] J. E. Dysart, A. Rainey, J. Owens, K. Chong, and V. Z. Lawson, "Double-blind lineup administration and the postidentification feedback effect," in Proceedings of the American Psychology Law Society Annual Meeting, Jacksonville, Fla, USA, March 2008.

[46] R. M. Haw, T. L. Mitchell, and G. L. Wells, "The influence of lineup administrator knowledge and witness perceptions on eyewitness identification decisions," in Proceedings of the International Congress of Psychology and Law, Edinburgh, Scotland, July 2003.

[47] M. B. Russano, J. J. Dickinson, S. A. Cass, M. B. Kovera, and B. L. Cutler, "Testing the effects of lineup administrator knowledge in simultaneous and sequential lineups," in Proceedings of the American Psychology-Law Society Biennial Meeting, Austin, Tex, USA, March 2002

[48] S. M. Greathouse and M. B. Kovera, "Instruction bias and lineup presentation moderate the effects of administrator knowledge on eyewitness identification," Law and Human Behavior, vol. 33, no. 1, pp. 70-82, 2009.

[49] S. D. Penrod, "How well are witnesses performing?" Criminal Justice Magazine, vol. 54, pp. 36-47, 2003.

[50] G. L. Wells and R. C. Lindsay, "On estimating the diagnosticity of eyewitness nonidentifications," Psychological Bulletin, vol. 88, no. 3, pp. 776-784, 1980.

[51] J. L. Austin, D. M. Zimmerman, L. M. Rhead, K. A. Almeida, and M. B. Kovera, "Suspect similarity to perpetrator moderates the effect of administrator knowledge on eyewitness identification accuracy," in Proceedings of the Annual Meeting of the American Psychology-Law Society, San Juan, Puerto Rico, USA, March 2012.

[52] L. M. Rhead, D. N. Rodriguez, V. Korobeynikov, J. H. Yip, and M. B. Kovera, "The effects of lineup administrator influence and mortality salience on witness identification accuracy accuracy," in Proceedings of the Annual Meeting of the Society for Applied Research in Memory and Cognition, New York, NY, USA, June 2011.

[53] D. M. Zimmerman, J. L. Austin, L. M. Rhead, K. A. Almeida, and M. B. Kovera, "Retention interval and suspect/perpetrator similarity moderate the effects of administrator knowledge on eyewitness identification," in Proceedings of the Annual Meeting of the American Psychology-Law Society, San Juan, Puerto Rico, USA, March 2012

[54] S. E. Clark, "Costs and benefits of eyewitness identification reform: psychological science and public policy," Perspectives on Psychological Science, vol. 7, pp. 238-259, 2012.

[55] A. B. Douglass, C. Smith, and R. Fraser-Thill, "A problem with double-blind photospread procedures: photospread administrators use one eyewitness's confidence to influence the identification of another eyewitness," Law and Human Behavior, vol. 29 , no. 5 , pp. 543-562, 2005. 
[56] S. E. Clark, "Eyewitness identification reform: data, theory, and due process," Perspectives on Psychological Science, vol. 7, pp. 279-283, 2012.

[57] G. L. Wells, N. K. Steblay, and J. E. Dysart, A test of the simultaneous $v$. sequential lineup methods: an initial report of the AJS national eyewitness identification field studies, American Judicature Society, Des Moines, Iowa, USA, 2011.

[58] A. L. Bradfield and G. L. Wells, "The perceived validity of eyewitness identification testimony: a test of the five Biggers criteria," Law and Human Behavior, vol. 24, no. 5, pp. 581-594, 2000.

[59] Manson v. Braithwaite, 432 U.S. 98, 1977.

[60] G. L. Wells and A. L. Bradfield, "'Good, you identified the suspect": feedback to eyewitnesses distorts their reports of the witnessing experience," Journal of Applied Psychology, vol. 83, no. 3, pp. 360-376, 1998.

[61] A. L. Bradfield, G. L. Wells, and E. A. Olson, "The damaging effect of confirming feedback on the relation between eyewitness certainty and identification accuracy," Journal of Applied Psychology, vol. 87, no. 1, pp. 112-120, 2002.

[62] D. N. Rodriguez and M. A. Berry, "System and estimator variables, eyewitness confidence, and the postidentification feedback effect," American Journal of Forensic Psychology, vol. 28, no. 2, pp. 17-37, 2010.

[63] C. Semmler, N. Brewer, and G. L. Wells, "Effects of postidentification feedback on eyewitness identification and nonidentification confidence," Journal of Applied Psychology, vol. 89, no. 2, pp. 334-346, 2004.

[64] A. B. Douglass and N. Steblay, "Memory distortion in eyewitnesses: a meta-analysis of the post-identification feedback effect," Applied Cognitive Psychology, vol. 20, no. 7, pp. 859-869, 2006.

[65] A. B. Douglass, N. Brewer, and C. Semmler, "Moderators of post-identification feedback effects on eyewitnesses' memory reports," Legal and Criminological Psychology, vol. 15, no. 2, pp. 279-292, 2010.

[66] D. B. Wright and E. M. Skagerberg, "Postidentification feedback affects real eyewitnesses," Psychological Science, vol. 18, no. 2, pp. 172-178, 2007.

[67] L. Garrioch and C. A. E. Brimacombe, "Lineup administrators' expectations: their impact on eyewitness confidence," Law and Human Behavior, vol. 25, no. 3, pp. 299-315, 2001.

[68] J. E. Dysart, V. Z. Lawson, and A. Rainer, "Blind lineup administration as a prophylactic against the postidentification feedback effect," Law and Human Behavior, vol. 36, no. 4, pp. 312-319, 2012.

[69] S. D. Charman and G. L. Wells, "The moderating effect of ecphoric experience on post-identification feedback: a critical test of the cues-based inference conceptualization," Applied Cognitive Psychology, vol. 26, pp. 243-250, 2012.

[70] N. K. Steblay, J. E. Dysart, and G. L. Wells, "Seventy-two tests of the sequential lineup superiority effect: a meta-analysis and policy discussion," Psychology, Public Policy, and Law, vol. 17, no. 1, pp. 99-139, 2011.

[71] N. K. Steblay, "What we know now: the evanston Illinois field lineups," Law and Human Behavior, vol. 35, no. 1, pp. 1-12, 2011.

[72] R. S. Nickerson, "Confirmation bias: a ubiquitous phenomenon in many guises," Review of General Psychology, vol. 2, no. 2, pp. 175-220, 1998.
[73] B. W. Behrman and S. L. Davey, "Eyewitness identification in actual criminal cases: an archival analysis," Law and Human Behavior, vol. 25, no. 5, pp. 475-491, 2001.

[74] P. A. Tollestrup, J. W. Turtle, and J.C. Yuille, "Actual witnesses to robbery and fraud: an archival analysis," in Adult Eyewitness Testimony: Current Trends and Developments, D. F. Ross, J. D. Read, and M. P. Toglia, Eds., pp. 144-162, Cambridge University Press, New York, NY, USA, 1994.

[75] D. N. Rodriguez and M. A. Berry, “The influence of administrator blindness on the recording of eyewitness identification decisions," Legal and Criminological Psychology. In press.

[76] Technical Working Group for Eyewitness Evidence, Eyewitness Evidence: A Guide for Law Enforcement [Booklet], United States Department of Justice, Office of Justice Programs, Washington, DC, 1999.

[77] Attorney General Guidelines for Preparing and Conducting Photo and Live Lineup Identification Procedures, Department of Law and Public Safety, Office of the Attorney General, Trenton, NJ, USA, 2001.

[78] Innocence Project, "Reevaluating lineups: Why witnesses make mistakes and how to reduce the chance of a misidentifications," 2009, http://www.innocenceproject.org/docs/ Eyewitness_ID_Report.pdf.

[79] American Bar Association, "Statement of best practices for promoting the accuracy of eyewitness identification procedures," 2004, http://www.americanbar.org/content/dam/ aba/migrated/2011_build/death_penalty_moratorium/reduce_ risk_convicting_innocent0804.authcheckdam.pdf.

[80] International Association of Chiefs of Police, Eyewitness Identification: Model Policy, International Association of Chiefs of Police, Alexandria, Va, USA, 2010.

[81] A. Bradfield and D. E. McQuiston, "When does evidence of eyewitness confidence inflation affect judgments in a criminal trial?" Law and Human Behavior, vol. 28, no. 4, pp. 369-387, 2004.

[82] A. B. Douglass and E. E. Jones, "Confidence inflation in eyewitnesses: seeing is not believing," Legal and Criminological Psychology. In press.

[83] J. M. Darley and P. H. Gross, "A hypothesis-confirming bias in labeling effects," Journal of Personality and Social Psychology, vol. 44, no. 1, pp. 20-33, 1983.

[84] J. E. Dysart, G. L. Wells, N. K. Steblay, and D. R. Mitchell, "A double-blind experiment of simultaneous versus sequential lineups using actual eyewitnesses: lab-field differences," in Proceedings of the annual meeting of the American Psychology Law Society, San Juan, Puerto Rico, USA, March 2012.

[85] D. N. Rodriguez and M. A. Berry, "Jurors' causal and counterfactual evaluations of factors affecting eyewitness evidence," in Proceedings of the Annual Meeting of the American Psychology Law Society, Vancouver, BC, Canada, March 2010.

[86] D. B. Wright, M. E. Carlucci, J. R. Evans, and N. S. Compo, "Turning a blind eye to double blind line-ups," Applied Cognitive Psychology, vol. 24, no. 6, pp. 849-867, 2010.

[87] B. L. Cutler, S. D. Penrod, and T. E. Stuve, "Juror decision making in eyewitness identification cases," Law and Human Behavior, vol. 12, no. 1, pp. 41-55, 1988.

[88] Model Policy and Procedure for Eyewitness Identification, State of Wisconsin Office of the Attorney General, Madison, Wis, USA. 

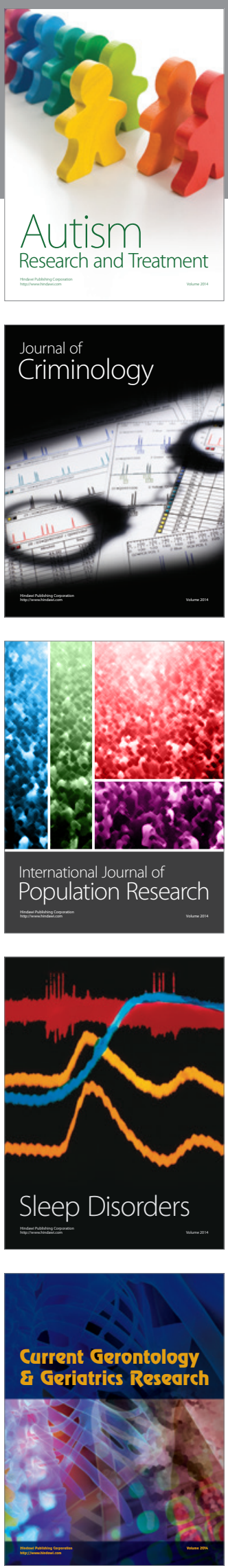
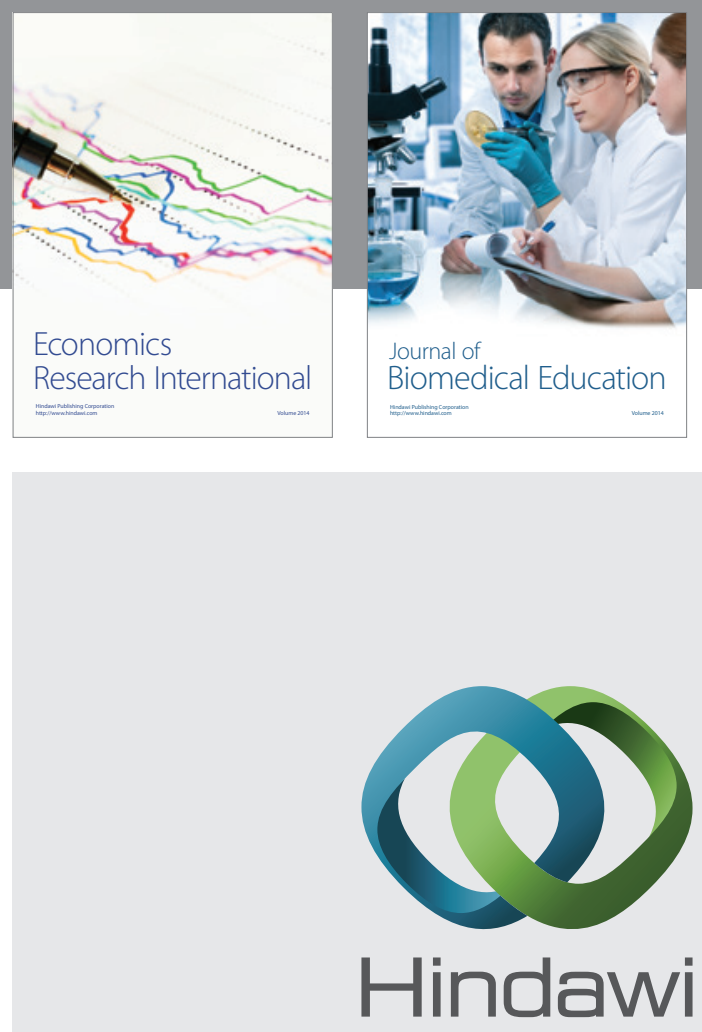

Submit your manuscripts at

http://www.hindawi.com
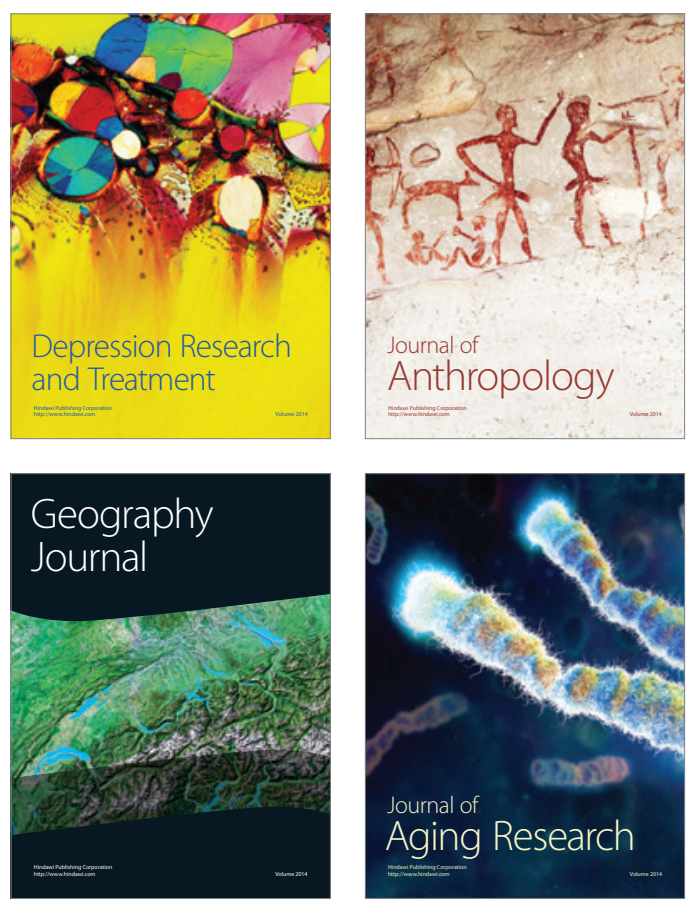
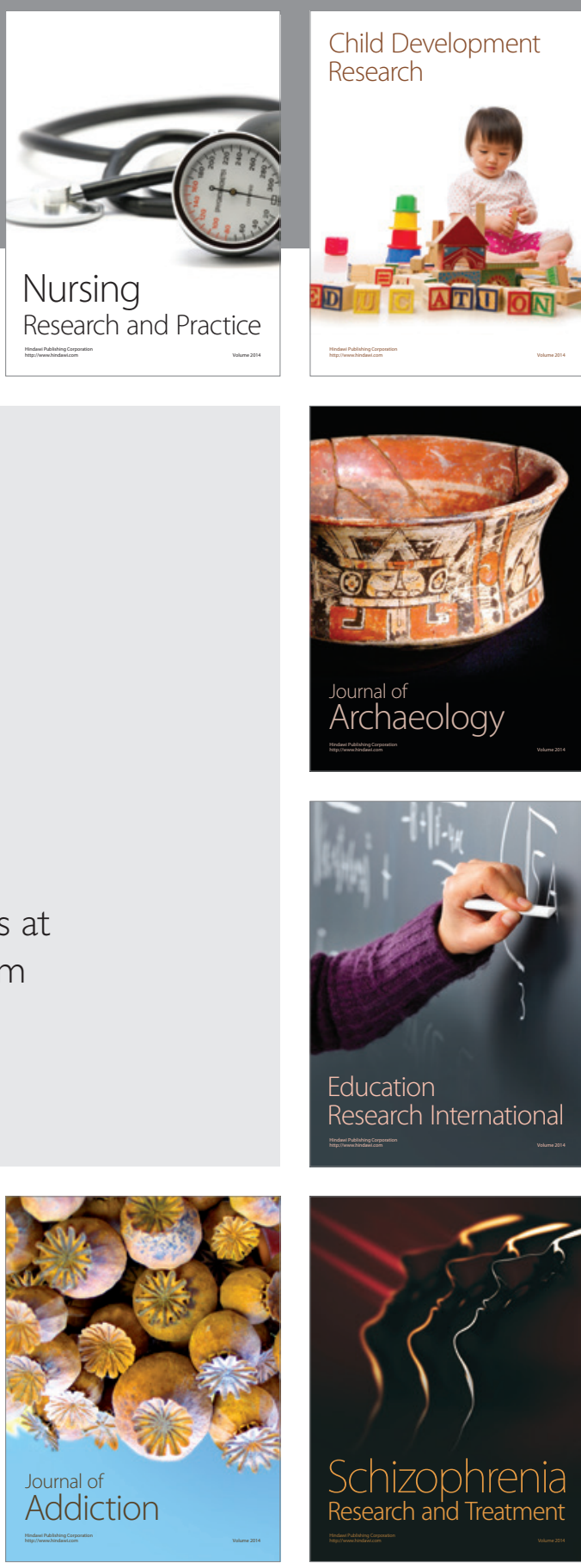

(D)
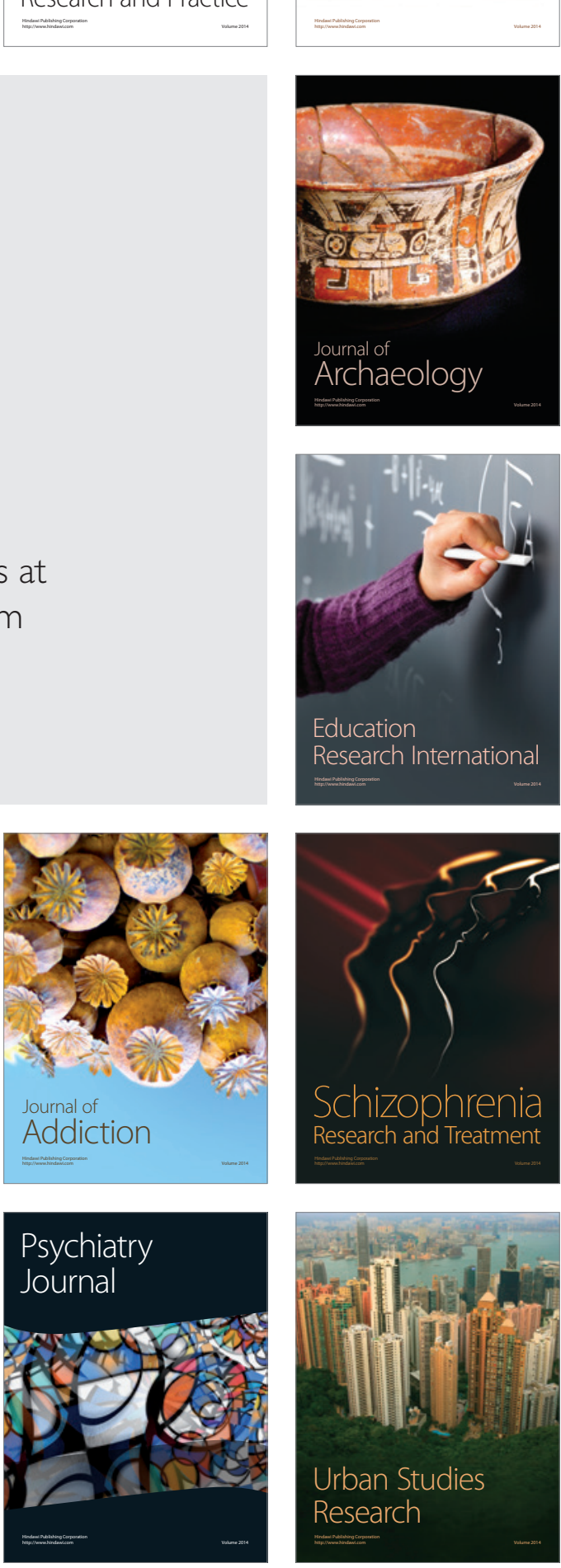